Seong-Kook Kim, Ji-Sook Hong*

\title{
The Relationship between Salesperson Competencies and Performance in the Korean Pharmaceutical Industry ${ }^{* *}$
}

This study investigates how competencies lead to performance. We propose that salespersons in the Korean pharmaceutical industry require three central competency dimensions: motive and traits, self-concept, and knowledge and skills. Further, we argue that the level of salesperson competencies is positively related to his/her performance, and that the quality of leader-member exchange positively moderates the relationship between competencies and performance. Results based on analyses of data from a sample of 457 salespersons and managers from 5 different pharmaceutical companies in Korea support our research model.

Key words: Competency, Salesperson Competency, Performance, Pharmaceutical Industry, Leader-Member Exchange, Korean Company

* Prof. Dr. Seong-Kook Kim, Department of Business Administration, Ewha Womans University, Seoul 120-750, Korea (South), Phone: +82-2-3277-2782, e-mail: skima@ewha.ac.kr.

Dr. Ji-Sook Hong, Senior Consultant, Insung IDS, Seoul, Korea.

E-mail: hongjs@insungids.com.

** Article received: February 27, 2004

Revised version accepted after double blind review: January 15, 2005. 


\section{Introduction}

Today, business practitioners are faced with many new opportunities to utilize competency methods to improve individual, team, and organizational performance. The use of competency models as the basis for performance appraisal and compensation has become widespread in business organizations. The competency movement was originally initiated by McClelland (1973) as an alternative to the trait and intelligence approaches in measuring and predicting human performance. Originally applied to the field of educational achievement testing, the competency approach was soon adopted for many business applications.

While some eminent figures in the field have viewed the competency movement as revolutionary and the best way to measure and predict human performance (Lawler, 1994; McClelland, 1994, 1973), others have questioned the validity of the approach (Barrett \& Depinet, 1991; Barrett, 1997). As the growth of competency applications continues to accelerate, it is appropriate to reflect on its influence on human performance. This article investigates how key aspects of competency lead to performance and explores moderating effects on the relationship between competencies and performance. This study through the implications derived from the results, attempts to provide managerial direction for development of salespersons in the pharmaceutical industry and development of competencies of salespersons.

\section{Theory and Hypotheses}

The definition of the term "competency" has evolved significantly over the years. The earliest definition provided by McClelland(1973) referred to competencies as components of performance associated with "clusters of life outcomes". McClelland (1973) questioned the traditional aptitude and achievement tests and tried to develop substitutable methods to improve those tests. He finally developed the so-called "Behavioral Event Interview (BEI)" to elaborate critical incident interview techniques. He tried to select the superior performers by distinguishing high from normal performers. In doing so, he utilized a competency concept (Klemp, 1978).

The term "competency" became popular when Boyatzis defined the super performers as "competent managers" (Boyatzis, 1982). Spencer and Spencer (1993) defined competency as internal characteristics of an individual that produced effective and superior performance. Sparrow (1996) divided into three categories: organizational competency, managerial compentency, and individual competency. He defined individual competency as list of behavioral characteristics related to job tasks. Schippment, Ash, Carr \& Hesketh (2000) defined competency as adequate knowledge to successfully complete job tasks. Clearly, there is a wide range of definitions, even among a fairly homogeneous expert population, underscoring the difficulty of pinpointing a standard definition of the term. This lack of consensus should not be too surprising, given the multiple domains in which the terms "competent" or "competency" are prevalent (Schippment, et al., 2000). Based on current thinking the definition that best fits the attributes of competency is given by Arthey \& Orth (1999): "A competency is a set of observable performance dimensions, including individual knowledge, skills, attitudes, and behaviors, as well as collective team, process, and or- 
ganizational capabilities, that are linked to high performance, and provide the organization with sustainable competitive advantage."

Although competency has been defined in several ways, its definition can be generalized as 'individual knowledge, skill, ability, or characteristics that bring excellent performance.' As the definition closely correlates with performance and it is a factor to be valid from correlation with performance at its development (Mirable, 1997), it is greatly expected to be a management tool of recruiting, developing, and evaluating highly potential people.

Regardless of the importance of competency, however, there are only a few researchers that have developed competency models and studied its correlation with performance because it requires cost and time to develop. However, for this paper we decided to use Spencer and Spencer's (1993) iceberg model to show relationship between competency and performance. Spencer and Spencer argued that there are surface and potential competencies. The surface competency, which consists of knowledge and skills, can be developed further by proper management. The potential competency consists of motive and traits and self-concept. Thus, we decided that by testing each of the competencies we can show that knowledge of the competencies that are capable of further development upon proper management will aid managers in future human resource planning and development. We believe that valuable managerial implications could be drawn.

We have divided the hypotheses into two groups: competencies and quality of leader-member-exchange relationship. The first group of hypotheses deals with each of types of competencies. The second group considers the moderating factor in the relationship between competencies and performance.

The Spencer and Spencer's (1993) iceberg model argues that competency may be composed of three key aspects: motive and traits, self-concept, and knowledge and skills (see Table 1).

Table 1: Sales Competency Model

\begin{tabular}{|l|l|l|}
\hline Model & Dimension & Competency \\
\hline \multirow{4}{*}{$\begin{array}{l}\text { Sales Competency } \\
\text { Model }\end{array}$} & Motive and Traits & $\begin{array}{l}\text { Impact and Influencing } \\
\text { Achievement Orientation } \\
\text { Analytical Thinking } \\
\text { Initiative/Persistence } \\
\text { Problem-solving }\end{array}$ \\
\cline { 2 - 3 } & & Flexibility \\
& Self-Concept & Self Confidence \\
& & Self Control \\
\cline { 2 - 3 } & Knowledge and Skills & $\begin{array}{l}\text { Aligning Customer/supplier Strategic } \\
\text { Objectives } \\
\text { Engaging in Self-appraisal and } \\
\end{array}$ \\
& & Continuous Learning \\
\hline
\end{tabular}

We suggest that a salesperson that has a higher level of competencies listed above will have higher performance than that of an average salesperson. Thus, we expect higher salesperson competencies to be positively related to individual performance. The three 
groupings of competencies, motive and traits, self-concept, and knowledge and skills, are composite variables of each of the competencies listed above.

Hypothesis 1: The level of salesperson competencies will be positively related to performance.

Hypothesis 1-1: The competency of motive and traits will be positively related to performance.

Hypothesis 1-2: The competency of self-concept will be positively related to performance.

Hypothesis 1-3: The competency of knowledge and skills will be positively related to performance.

According to Leader-Member-Exchange (LMX) Theory, the quality of social exchange between in-group and out-group is different: members of in-group receive more attention and recognition from leaders and they are relatively highly satisfied with their jobs and more committed to the organization, in comparison with members of the out-group (Dansereau, Graen, and Haga, 1975). Dansereau, et al., (1975) developed a measurement tool using two factors to test for leader-member exchange relationship, and Graen, Novak, and Sommerkamp (1982) developed it further using seven factors. Past research on leader-member relationships showed that quality of the leader-member exchange relationship was an influencing factor.

In previous socialization research on salespersons, the dyad relationship between leader and followers has been explored to explain the factors that support the socialization of salespersons (Dubinsky, Howell, Ingram, and Bellenger, 1986). Some researchers tried to investigate the role of LMX in explaining the leadership for salespersons (DelVecchio, 1998; Weitz, 1981). DelVecchio (1998) examined the relationship between sales performance and LMX and between LMX and competency of salesperson. Weitz (1981) in his contingency framework used the quality of relationship between a customer and a salesperson as a moderating factor in the relationship between sales performance and resources of the salesperson. He set up a conceptual hypothesis suggesting that relationship between a customer and a salesperson will act as a moderating factor, but did not actually test for the relationship. He noted also that the previous studies looked at mainly antecedents that affect sales performance, but there lacks research that also looks at moderating variables in the relationship. Given the previous research, we adopted LMX-theory to explain moderating effect of quality of LMX in the relationship between the competency and performance. It is likely that LMX will influence the relationship between competency and performance. Thus, we hypothesize that the quality of leader-member exchange moderates the relationship between the competency and performance. The quality of leader-member exchange is also a composite variable.

Hypothesis 2: The quality of leader-member exchange will positively moderate the relationship between competencies and performance.

Hypothesis 2-1: The quality of leader-member exchange will positively moderate the relationship between competency of motive/traits and performance.

Hypothesis 2-2: The quality of leader-member exchange will positively moderate the relationship between competency of self-concept and performance. 
Hypothesis 2-3: The quality of leader-member exchange will positively moderate the relationship between competency of knowledge/skills and performance.

We are also using five control variables that may affect a subordinate's performance in this study. They are company sales, regional difference, job experience, education level, and job experience of the superior.

\section{Methods}

\section{Samples and Respondents}

We conducted a pilot study to find out competencies for salespersons in the pharmaceutical industry. The BEI interview techniques were used for the pilot study and 58 salespersons from several Korean pharmaceutical companies took part in the interview. We summarized 20 items in competency through this pilot study. Factor analysis and reliability test have been conducted to test the validity and reliability of the competency items. Finally, we define 10 salesperson competencies as a result of distinguishing the high performers from the low performers as similar to Mirable's (1997) study. Those competencies are grouped into three dimensions: motive and traits (impact and influencing, achievement orientation, initiative/persistence, problem-solving, and analytical thinking), self-concept (flexibility, self confidence, and self control), and knowledge and skills (aligning customer/supplier strategic objectives and engaging in self-appraisal and continuous learning).

Table 2: Demographic Description of Respondents $(\mathbf{N}=457)$

\begin{tabular}{|l|l|r|r|}
\hline Variable & Feature & Frequency & Percent(\%) \\
\hline 1. Gender(subordinates) & Male & 449 & 98.2 \\
& Female & 8 & 1.8 \\
\hline 2. Gender(superiors) & Male & 457 & 100.0 \\
& Female & 0 & 0 \\
\hline 3. Age (subordinates) & $20-24$ & 17 & 3.7 \\
& $25-30$ & 238 & 52.2 \\
& $31-35$ & 151 & 33.1 \\
& $36-40$ & 45 & 9.8 \\
& 41 and older & 6 & 1.2 \\
\hline 4. Age (superiors) & $30-35$ & 78 & 17.1 \\
& $36-40$ & 250 & 54.7 \\
& $41-45$ & 88 & 19.3 \\
& 46 and older & 32 & 7.1 \\
\hline 5. Position (subordinates) & employees & 219 & 47.9 \\
& acting section chief & 179 & 39.2 \\
& section chief & 51 & 11.2 \\
& deputy manager & 5 & 1.1 \\
& manager & 1 & 0.2 \\
\hline 6. Position (superiors) & acting section chief & 36 & 7.9 \\
& section chief & 161 & 35.2 \\
& deputy manager & 180 & 39.4 \\
& manager & 80 & 17.5 \\
\hline
\end{tabular}


Our sample for this study consists of salespersons from five organizations in the pharmaceutical industry in South Korea. All surveys were hand-distributed and returned directly to the researchers by mail. Of 570 surveys distributed to salespersons, 457 usable surveys were returned (an 80.2 percent response rate).

Respondents provided data on competencies, individual performance, and other personal data. In addition to the self-report surveys from focal subjects, we obtained additional information from companies in the pharmaceutical industry, to which the respondents belong and performed in-depth interviews, "Behavioral Event Interviews (BEI)".

Table 2 shows basic demographic data about all 457 respondents of the survey.

\section{Measures and Procedures}

\section{Dependent variable}

Accomplishment ratio of the sales goals was assessed using the real data of individual sales realized within the first quarter of the year 2003.

\section{Independent variables}

Three competency dimensions: Motive and traits, self-concept, and knowledge and skills were adapted from Spencer and Spencer's iceberg model of competency. These three variables are composite variables. Motive and traits is a composite of responses from I-1 through I-5. Self-concept is a composite of responses from I-6 through I-8. Knowledge and skill is a composite of responses from I-9 through I-10.

\section{Moderating variable}

The quality of leader-member exchange was included in the study as a moderator, which moderates the relationship between competencies and individual performance. The leader-member exchange variable was adapted from DelVecchio (1998). This is a composite variable of five items in Part II of the questionnaire.

\section{Control variables}

We controlled for contextual factors that may influence the relationships in the model. Sales, job experience, education, the product market, and regional differences were adopted in the study as control variables.

Figure 1 represents the research model of this study. We examined relationships between competencies and performance in the research model. Hypothesized moderation effect was also assessed in accordance with hierarchical regression analysis.

Figure 1: Research Model of the Study

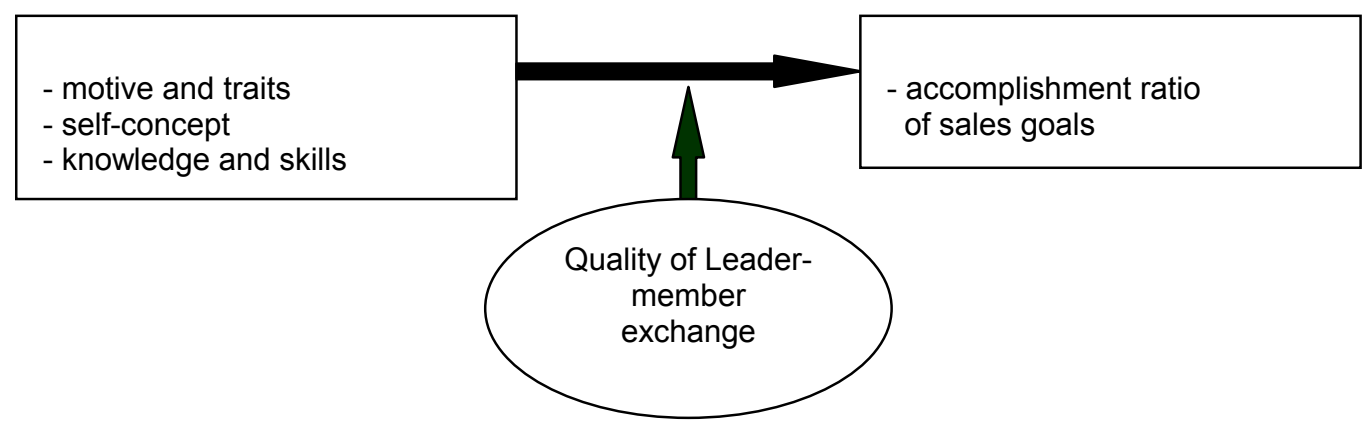




\section{Results}

\section{The salesperson competencies}

Correlations were computed to confirm whether 10 competency variables have strong inter-correlations. Descriptive statistics and a correlation matrix for the competencies are presented in Table 3 . The results suggest that 10 components have strong correlation coefficients ( $\mathrm{r}=$ between .499 and .743 ) and that they comprise a single variable: sales competency.

Table 3: Correlations among Components of Competency $(\mathrm{N}=457)$

\begin{tabular}{|c|c|c|c|c|c|c|c|c|c|c|c|c|}
\hline Variables & mean & std & 1 & 2 & 3 & 4 & 5 & 6 & 7 & 8 & 9 & 10 \\
\hline $\begin{array}{l}\text { 1. Impact and } \\
\text { influencing }\end{array}$ & 3.66 & .807 & 1 & & & & & & & & & \\
\hline $\begin{array}{l}\text { 2. achievement } \\
\text { orientation }\end{array}$ & 3.84 & .834 & $.681^{* *}$ & 1 & & & & & & & & \\
\hline $\begin{array}{l}\text { 3. analytical } \\
\text { thinking }\end{array}$ & 3.60 & .793 & $.600^{\star *}$ & $.636^{\star *}$ & 1 & & & & & & & \\
\hline $\begin{array}{l}\text { 4. initiative/ } \\
\text { persistence }\end{array}$ & 3.69 & .977 & $.643^{\star *}$ & $.743^{\star *}$ & $.657^{\star *}$ & 1 & & & & & & \\
\hline 5. flexibility & 3.64 & .912 & $.594^{* *}$ & $.626^{\star *}$ & $\begin{array}{l}.592 \\
* *\end{array}$ & $\begin{array}{l}.611 \\
* *\end{array}$ & 1 & & & & & \\
\hline $\begin{array}{l}\text { 6. problem } \\
\text { solving }\end{array}$ & 3.41 & .992 & $.561^{* *}$ & $.580^{\star *}$ & $\begin{array}{l}.697 \\
\star *\end{array}$ & $\begin{array}{l}.636 \\
\star \star\end{array}$ & $\begin{array}{l}.618 \\
* *\end{array}$ & 1 & & & & \\
\hline $\begin{array}{l}\text { 7. self } \\
\text { confidence }\end{array}$ & 3.53 & .941 & $.588^{* *}$ & $.642^{\star *}$ & .605 & .649 & .616 & $.615^{\star \star}$ & 1 & & & \\
\hline $\begin{array}{l}\text { 8.self-apprais. } \\
\text { cont. learning }\end{array}$ & 3.57 & 1.011 & $.499^{\star *}$ & $.569^{\star \star}$ & $\begin{array}{l}.584 \\
\star *\end{array}$ & $\begin{array}{l}.608 \\
* *\end{array}$ & $\begin{array}{l}.590 \\
* *\end{array}$ & $\begin{array}{l}.602 \\
\star *\end{array}$ & $\begin{array}{l}.572 \\
* \star\end{array}$ & 1 & & \\
\hline $\begin{array}{l}\text { 9. self } \\
\text { control }\end{array}$ & 3.76 & .885 & $.584^{* *}$ & $.626^{\star \star}$ & $\begin{array}{l}.527 \\
* *\end{array}$ & $\begin{array}{l}.626 \\
* *\end{array}$ & $\begin{array}{l}.657 \\
* *\end{array}$ & $\begin{array}{l}.578 \\
* *\end{array}$ & $\begin{array}{l}.620 \\
* *\end{array}$ & $\begin{array}{l}.580 \\
* *\end{array}$ & 1 & \\
\hline $\begin{array}{l}\text { 10. strategic } \\
\text { objectives }\end{array}$ & 3.55 & .799 & $.501^{\star *}$ & $.558^{\star \star}$ & $\begin{array}{l}.611 \\
* *\end{array}$ & $\begin{array}{l}.569 \\
* *\end{array}$ & $\begin{array}{l}.564 \\
* *\end{array}$ & $\begin{array}{l}.603 \\
* *\end{array}$ & $\begin{array}{l}.539 \\
* *\end{array}$ & $\begin{array}{l}.583 \\
* \star\end{array}$ & $\begin{array}{l}.586 \\
\star \star\end{array}$ & 1 \\
\hline
\end{tabular}

${ }^{* *} p<0.01$ Two-tailed tests.

\section{Test of Hypothesis 1}

We analyzed the causal relationship between the competencies and individual performance controlling for several context variables, such as sales, the product market, job experience (subordinates and superiors), and education level of the salespersons. We analyzed three dimensions of competencies as competency variables. A stepwise multiple regression analysis has been conducted to test the Hypothesis 1.

Table 4 represents the results of the multiple regression analysis. Stage 2 shows an increase in R-square by 13.7\%. Competency dimensions "motive and traits" and "selfconcept" represent positive relationship to performance on the $95 \%$ and $99 \%$ significance level, respectively, whereas "knowledge and skills" showed no significant relationship to performance. Thus, Hypotheses 1-1 and 1-2 are supported and Hypothesis 1-3 is not supported. 
Table 4: Multiple Regression Analysis of Competencies and Performance $(\mathbf{N}=457)$

\begin{tabular}{|c|c|c|c|c|c|}
\hline & & \multicolumn{2}{|c|}{ Model 1} & \multicolumn{2}{|c|}{ Model 2} \\
\hline \multicolumn{2}{|c|}{ Variable } & Beta & $\mathrm{p}$ & Beta & $\mathrm{p}$ \\
\hline $\begin{array}{l}\text { Control } \\
\text { Variables }\end{array}$ & $\begin{array}{l}\text { Sales } \\
\text { Product Market Dummy } 1 \\
\text { Product Market Dummy } 2 \\
\text { Regional Difference } \\
\text { Job Experience } \\
\text { Education level } \\
\text { Job Experience (superiors) }\end{array}$ & $\begin{array}{r}.105 \\
-.063 \\
-.012 \\
.164 \\
.090 \\
-.057 \\
-.016\end{array}$ & $\begin{array}{l}.030 \\
.239 \\
.810 \\
.001^{\star *} \\
.081 \\
.225 \\
.740\end{array}$ & $\begin{array}{r}.058 \\
-.044 \\
-.005 \\
.150 \\
.029 \\
-.057 \\
-.020\end{array}$ & $\begin{array}{l}.204 \\
.381 \\
.918 \\
.001^{* *} \\
.551 \\
.192 \\
.652\end{array}$ \\
\hline $\begin{array}{l}\text { Independent } \\
\text { Variables }\end{array}$ & $\begin{array}{l}\text { Motive and Traits } \\
\text { Self-Concept } \\
\text { Knowledge and Skills }\end{array}$ & & & $\begin{array}{l}.161 \\
.198 \\
.048\end{array}$ & $\begin{array}{l}.030^{*} \\
.010^{\star *} \\
.463\end{array}$ \\
\hline \multicolumn{2}{|l|}{ R-square } & \multicolumn{2}{|c|}{.048} & \multicolumn{2}{|c|}{.185} \\
\hline \multicolumn{2}{|c|}{ Adjusted R-square } & \multicolumn{2}{|c|}{.033} & \multicolumn{2}{|c|}{.167} \\
\hline \multicolumn{2}{|c|}{ R-square change } & & & \multicolumn{2}{|c|}{.137} \\
\hline \multicolumn{2}{|l|}{$\mathrm{F}$} & \multicolumn{2}{|c|}{3.215} & \multicolumn{2}{|c|}{10.038} \\
\hline \multicolumn{2}{|l|}{ Sig. $F$} & \multicolumn{2}{|c|}{$.002^{* *}$} & \multicolumn{2}{|c|}{$.000^{\star *}$} \\
\hline
\end{tabular}

${ }^{*} p<0.05{ }^{* *} p<0.01$

\section{Test of Hypothesis 2}

We analyzed the moderating effect of "quality of leader-member exchange" in the relationship between competencies and performance. For the analysis we conducted hierarchical multiple regression analysis.

Table 5: Hierarchical Regression Analysis of Competencies, Performance, and LMX $(\mathrm{N}=457)$

\begin{tabular}{|c|c|c|c|c|c|c|c|c|c|}
\hline \multirow{2}{*}{\multicolumn{2}{|c|}{ Variables }} & \multicolumn{2}{|c|}{ Model 1} & \multicolumn{2}{|c|}{ Model 2} & \multicolumn{2}{|c|}{ Model 3} & \multicolumn{2}{|c|}{ Model 4} \\
\hline & & Beta & $\mathrm{p}$ & Beta & $\mathrm{p}$ & Beta & $\mathrm{p}$ & Beta & $\mathrm{p}$ \\
\hline $\begin{array}{l}\text { Control } \\
\text { Variables }\end{array}$ & $\begin{array}{l}\text { Sales } \\
\text { Product Market } 1 \\
\text { Product Market } 2 \\
\text { Region Difference } \\
\text { Job Experience } \\
\text { Education } \\
\text { Job Experience } \\
\text { (Superior) } \\
\end{array}$ & $\begin{array}{r}.105 \\
-.063 \\
-.012 \\
.164 \\
.090 \\
-.057 \\
-.016\end{array}$ & $\begin{array}{r}.030^{*} \\
.239 \\
.810 \\
.001^{* *} \\
.081 \\
.225 \\
.740\end{array}$ & $\begin{array}{r}.058 \\
-.044 \\
-.005 \\
.150 \\
.029 \\
-.057 \\
-.020\end{array}$ & $\begin{array}{r}.204 \\
.381 \\
.918 \\
.001^{* *} \\
.551 \\
.192 \\
.652\end{array}$ & $\begin{array}{r}.050 \\
-.039 \\
-.006 \\
.153 \\
.032 \\
-.052 \\
-.014\end{array}$ & $\begin{array}{r}.266 \\
.430 \\
.898 \\
.000^{* *} \\
.511 \\
.230 \\
.753\end{array}$ & $\begin{array}{r}.033 \\
-.023 \\
.006 \\
.148 \\
.037 \\
-.045 \\
-.016\end{array}$ & $\begin{array}{r}.466 \\
.637 \\
.900 \\
.001^{* *} \\
.438 \\
.299 \\
.713\end{array}$ \\
\hline $\begin{array}{l}\text { Indepen- } \\
\text { dent } \\
\text { Variables }\end{array}$ & $\begin{array}{l}\text { Motive and Traits } \\
\text { Self-Concept } \\
\text { Knowledge and } \\
\text { Skills }\end{array}$ & & & $\begin{array}{l}.161 \\
.198 \\
.048\end{array}$ & $\begin{array}{l}.030^{*} \\
.010^{* *} \\
.0463\end{array}$ & $\begin{array}{l}.153 \\
.176 \\
.033\end{array}$ & $\begin{array}{c}.040^{*} \\
.024^{*} \\
.623\end{array}$ & $\begin{array}{r}.681 \\
.190 \\
-.809\end{array}$ & $\begin{array}{l}.050^{*} \\
.013^{*} \\
.001^{* *}\end{array}$ \\
\hline Moderator & LMX & & & & & .086 & .085 & -.129 & .526 \\
\hline $\begin{array}{l}\text { Inter- } \\
\text { action }\end{array}$ & $\begin{array}{l}M T{ }^{*} \text { LMX } \\
S C \text { * LMX } \\
\text { KS * LMX }\end{array}$ & & & & & & & $\begin{array}{r}-.817 \\
.710 \\
.570 \\
\end{array}$ & $\begin{array}{r}.111 \\
.005^{\star *} \\
.030^{\star}\end{array}$ \\
\hline \multicolumn{2}{|l|}{ R-square } & \multicolumn{2}{|l|}{.048} & \multicolumn{2}{|l|}{.185} & \multicolumn{2}{|l|}{.191} & \multicolumn{2}{|l|}{.218} \\
\hline \multicolumn{2}{|c|}{ Adjusted R-square } & \multicolumn{2}{|l|}{.033} & \multicolumn{2}{|l|}{.167} & \multicolumn{2}{|l|}{.170} & \multicolumn{2}{|l|}{.193} \\
\hline \multicolumn{2}{|c|}{ R-square change } & & \multicolumn{2}{|l|}{.137} & \multicolumn{2}{|l|}{.006} & \multicolumn{2}{|l|}{.027} \\
\hline \multicolumn{2}{|l|}{$\mathrm{F}$} & \multicolumn{2}{|l|}{3.215} & \multicolumn{2}{|l|}{10.038} & \multicolumn{2}{|l|}{9.437} & \multicolumn{2}{|l|}{8.709} \\
\hline \multicolumn{2}{|l|}{ Sig. F. } & \multicolumn{2}{|c|}{$.002^{* *}$} & \multicolumn{2}{|l|}{$.000^{* *}$} & \multicolumn{2}{|l|}{$.000^{* *}$} & \multicolumn{2}{|l|}{$.000^{* *}$} \\
\hline
\end{tabular}

${ }^{*} p<0.05{ }^{* *} p<0.01$ 
Table 5 shows the results of the hierarchical regression analysis. The analysis represents that the quality of LMX positively moderates the relationships between "selfconcept" and performance, as well as between "knowledge and skills" and performance. These results suggest that as the competencies like self-concept and knowledge/skills increase, performance will also increase. However, the increase shows differently depending on the high and low LMX groups. The high LMX group reports a stronger increase compared to the low LMX group.

Thus, Hypothesis 2 is partially supported. That is, we find support for Hypotheses 2-2 and 2-3 but no support is found for Hypothesis 2-1.

\section{Discussion}

We assessed the future performance of a salesperson based on his or her competencies in the past. The results of this study suggest that two of the three dimensions of competency, motive and traits and self-concept have positive causal effect on human performance. Further, the quality of leader-member exchange moderates the relationship between "self-concept" and performance, as well as between knowledge and skills and performance. This suggests that companies should develop education and development programs for salespersons to develop their competencies. Knowledge and skills and self-concept competencies can be improved through appropriate training and development. Through better understanding of the role and leadership of superior, the quality of leader-member exchange relationship can be improved. With regards to motive and traits competency, rather than attempting to improve upon this competency, the organization should select the individuals that best have the characteristics of this competency dimension.

Limitations and Future Research: There are several limitations in this study. First, it is difficult to fully substantiate causal arguments with cross-sectional data. Longitudinal studies could provide more data source for analyzing relationships between competencies and human performance. Second, this research focused on salespersons in Korean pharmaceutical industry. Thus, it is difficult to generalize the research findings of this study.

\section{Conclusions and managerial implications}

We examined the causal relationship between the future (individual) performance and competencies which salespersons obtained from performance in the past. We argue that competencies are important for predicting the future performance in organizations.

Competencies such as impact and influencing, achievement orientation, analytical thinking, initiative/persistence, problem-solving (motive and traits), flexibility, self confidence, and self-control (self-concept) are regarded as meaningful components of competency which have direct influence on salesperson's performance.

The quality of leader-member exchange mediating competency-performance relations suggests the importance of leadership in competency models. The desirable relations with superiors in organizations would strengthen the ties between salespersons' competencies and goal accomplishments. 
This study provides practitioners of management with a practical scheme of competency to enhance potential and performance of people by suggesting effective guidelines for development in the competency field. As competency models evolve to meet rapidly changing business needs, practitioners should be well informed to utilize competency methods to improve individual, team, and organizational performance.

\section{References}

Arthey, T. R./Orth, M. S. (1999): Emerging competency methods for the future. In: Human Resource Management, Fall, 38(3): 215-226.

Barrett, G. (1997): Paper presented at the Society for Industrial/Organizational Psychologist (SIOP) Conference. St. Louis.

Barrett, G./Depinet, R. (1991): A reconsideration of testing for competence rather than intelligence. In: American Psychologist, 46(10): 1012-1024.

Boyatzis, R. (1982): The competent manager: A model for effective performance, New York: John Wiley.

Dansereau, F. Jr./Graen, G./Haga, W. (1975): A vertical dyad linkage approach within formal organizations: A longitudinal investigation of the role making process. In: Allen, R. W./Porter, L. W. (1983): Organizational Influence Processes, Chicago: Scott, Foresman and Company.

DelVecchio, S. K. (1998): The quality of salesperson-manager relationship: the effect of latitude, loyalty and competence. In: Journal of Personal Selling \& Sales Management, 18(1): 31-47.

Dubinsky, A. J./Howell, R. D./Ingram, T. N./Bellenger, D. N. (1986): Salesforce socialization. In: Journal of Marketing, 50(4): 192-207.

Graen, G./Novak, M./Sommerkamp, P. (1982): The effects of leader-member exchange and job design on productivity and job satisfaction: Testing a dual attachment model. In: Organizational Behavior and Human Performance, 30: 109-131.

Klemp, G. O. (1978): Job Competence Assessment. Boston: McBer and Company.

Lawler, E. (1994): From job-based to competency-based organizations. In: Journal of Organizational Behavior, 15: 3-15.

McClelland, D. (1973): Testing for competence rather than intelligence. In: American Psychologist, 28: 114.

McClelland, D. (1994): The knowledge testing educational complex strides back. In: American Psychologist, 49: 66-69.

Mirable, R. (1997): Everything you wanted to know about competency modeling. In: Training and Development, August: 73-77.

Schippment, J. S./Ash, R. A./Carr, L./Hesketh, B. et al. (2000): The practice of competency modeling. In: Personnel Psychology, Autumn, 53(3): 703-740.

Sparrow, P. (1996): Competency based pay: Too good to be true. In: People Management, December, 5: 22-25.

Spencer, L. M./Spencer, S. M. (1993): Competence at Work. New York: John Wiley.

Weitz, B. (1981): Effectiveness in sales interactions: A contingency framework. In: Journal of Marketing, 45 (Winter): 85-103. 


\section{Appendix \\ QUESTIONNAIRE: Respondents-Superior \& Self}

A competency is an underlying characteristic of an individual that is causally related to criterion-referenced, effective and/or superior performance in a job or situation.

I. After reading the two types of definitions of each sales competency carefully, please evaluate your subordinate's (or your) level of competencies and how important each sales competency is when he/she (or you) performs his/her (or your) job using the scale listed below.

\begin{tabular}{|c|c|}
\hline score & Level of competency \\
\hline 7 & very high: the level of competency exceeds expectations consistently \\
\hline 6 & $\begin{array}{l}\text { high: the level of competency meets expectations or above basic expectations } \\
\text { consistently }\end{array}$ \\
\hline 5 & $\begin{array}{l}\text { somewhat high: the level of competency meets expectations or above basic } \\
\text { expectations occasionally }\end{array}$ \\
\hline 4 & - average: the level of competency meets expectations consistently \\
\hline 3 & $\begin{array}{l}\text { below average: the level of competency meets expectations frequently or below } \\
\text { basic expectations occasionally }\end{array}$ \\
\hline 2 & $\begin{array}{l}\text { low : the level of competency is below basic expectations consistently or } \\
\text { insufficiently occasionally }\end{array}$ \\
\hline 1 & very low: the level of competency is insufficient \\
\hline
\end{tabular}

\begin{tabular}{|c|l|}
\hline score & Importance of competency \\
\hline 7 & very high: this competency is very highly important to perform the job of sales \\
\hline 6 & high: this competency is highly important to perform the job of sales \\
\hline 5 & somewhat high: sales \\
\hline 4 & average: this competency is somewhat highly important to perform the job of \\
\hline 3 & low: this competency is less important to perform the job of sales \\
\hline 2 & very low: this competency is not important to perform the job of sales \\
\hline 1 &
\end{tabular}




\section{Evaluate the competencies related to Motive/Traits (I-1 through I-5).}

\section{I-1. Impact and Influencing}

1) An ability or behavioral characteristics to build trust, to persuade, convince, influence, or impress others in order to get support for his/her agenda.

2) An ability or behavioral characteristics to maintain his/her opinion by persuading others to adopt the course of action that he/she wishes, while showing understanding of their opinion.

I-2. Achievement Orientation

1) An ability or behavioral characteristics showing a tenacity to accomplish tasks to the end, desire to achieve high, or to compete against a standard of excellence.

2) An ability or behavioral characteristics to set and act to reach challenging goals for self and others.

I-3. Analytical Thinking

1) An ability or behavioral characteristics to understand a situation by breaking it into smaller pieces and organizing the parts in a systematic way or to show the implications of a problem in a step-by step causal way.

2) An ability or behavioral characteristics to make inferences about customer's preferences or concerns and to anticipate and prepare for obstacles through inductive reasoning.

I-4. Initiative/ Persistence

1) An ability or behavioral characteristics to do more than is required or expected in the job or finding or creating new opportunities.

2) An ability or behavioral characteristics to refuse to give up when faced with obstacles or rejection and to seize and act on opportunities that will not be fully realized for years to come.

\section{I-5. Problem - Solving}

1) An ability or behavioral characteristics to predict problems, define the cause of the problem, seek idea, or suggest solutions and alternatives for execution.

2) An ability or behavioral characteristics to generate new ideas or innovative solutions and develop customized service and product, and to create a new paradigm.

\section{Evaluate the competencies related to Self-Concept (I-6 through I-8).}

I-6. Flexibility

1) An ability or behavioral characteristics to adapt to and work effectively with a variety of situations, individuals, or groups.

2) An ability or behavioral characteristics to understand and appreciate different and opposing perspectives on an issue, to adapt an approach to satisfy customers, and to easily accept changes in one's own organization or job requirements.

I-7. Self-Confidence

1) An ability or behavioral characteristics to express one's belief in his or her own capability to accomplish a task, especially in dealing with increasingly challenging circumstances, and to handle failures positively.

2) An ability or behavioral characteristics to express confidence in one's own ability and to deal with failure in an optimistic way.

\section{I-8. Self-Control}

1) An ability or behavioral characteristics to keep emotions under control and to restrain negative actions when tempted or when faced with opposition or hostility from others

2) An ability or behavioral characteristics not to let one's own emotion interfere with one's job performance but to respond constructively to problems or complaints from customers even under stress. 
Evaluate the competencies related to Knowledge/Skill (I-9 through I-10).

I-9. Aligning Customer/Supplier Strategic Objectives

1) An ability or behavioral characteristics to keep abreast of new development and innovations that affect customers' business strategies and to analyze and offer opportunities in customers' markets in the view of customers' long-term needs.

2) An ability or behavioral characteristics to set a challenging and success-seeking goal that can add value to customers and one's company through analysis of the trends in changing environment, market opportunities, and threats.

I-10.Engaging in self-appraisal and continuous learning

1) An ability or behavioral characteristics to seek feedback regularly from one's customers, peers, and superiors and to keep learning about company product and for self-development.

2) An ability or behavioral characteristics to get an assessment of one's performance through various sources and to keep leaning for self-development.

II. Please evaluate the relationship between your subordinates/superior and you.

II-1. The relationship between superior/subordinate and me is friendly.

II-2. The relationship between superior/subordinate and me is compatible.

II-3. The relationship between superior/subordinate and me is formal.

II-4. The relationship between me and superior/subordinate is excellent.

II-5. The relationship between me and superior/subordinate is close.

\begin{tabular}{|l|ccccccccl|}
\hline II-1 & hostile & 1 & 2 & 3 & 4 & 5 & 6 & 7 & friendly \\
\hline IV-2 & incompatible & 1 & 2 & 3 & 4 & 5 & 6 & 7 & compatible \\
\hline IV-3 & formal & 1 & 2 & 3 & 4 & 5 & 6 & 7 & informal \\
\hline IV-4 & inferior & 1 & 2 & 3 & 4 & 5 & 6 & 7 & superior \\
\hline IV-5 & distant & 1 & 2 & 3 & 4 & 5 & 6 & 7 & close \\
\hline
\end{tabular}

III. Please answer the following.

$\begin{array}{lll}\text { 1. Sex 1) male 2) female } & \end{array}$

2. Age ( )

3. Department in which you work (

4. Work experience in sales area:

1) less than 1 year 2) 1-2 years 3) 2-3 years 4) 3-4 years

5) 4-5 years 6) more than 5 years

5. Work experience as a manager:
1) $0-6$ months
2) 6 months-1 year 3) 1-2 years
4) 2-3 years
4) 3-4 years
5) 4-5 years
6) more than 5 years

Thank you for your participation. 